\title{
Krzysztof Adamowicz
}

Uniwersytet Przyrodniczy w Poznaniu

e-mail: adamowic@up.poznan.pl

\section{Piotr Szczypa}

Uniwersytet Szczeciński

e-mail: piotr.szczypa@wp.pl

\section{DETERMINANTY RENTOWNOŚCI PRODUKCJI SUROWCA DRZEWNEGO I ICH WPLYW NA IMPLEMENTACJĘ INSTRUMENTÓW RACHUNKOWOŚCI ZARZĄDCZEJ W LEŚNICTWIE} PROFITABILITY DETERMINANTS OF WOOD MATERIAL PRODUCTION AND THEIR IMPACT ON THE IMPLEMENTATION OF MANAGEMENT ACCOUNTING INSTRUMENTS IN FORESTRY

DOI: $10.15611 / \mathrm{pn} .2017 .471 .01$

JEL Classification: O44, Q23, Q56, M41

Streszczenie: Produkcja drewna jest jedną z najdłuższych produkcji przyrodniczych, trwającą średnio około 100 lat. Jej specyficzne uwarunkowania mają bezpośredni wpływ na czynniki kształtujące przychody i koszty związane z gospodarką leśną. Czynniki te determinują rentowność produkcji drewna i są związane z fazą rozwoju drzewostanów. Specyficzne, ekonomiczne uwarunkowania produkcji leśnej są podstawową przyczyną braku możliwości bezpośredniej implementacji narzędzi rachunkowości zarządczej z praktyki przedsiębiorstw produkcyjnych (w tym produkcji rolnej) na grunt jednostek prowadzących gospodarkę leśną. Celem artykułu jest: (1) zidentyfikowanie czynników wpływających na rentowność produkcji drewna; (2) pogrupowanie determinant produkcji drewna w ramach faz rozwojowych drzewostanów; (3) określenie wpływu determinant produkcji drewna na możliwość zastosowania narzędzi rachunkowości zarządczej w jednostkach produkujących drewno.

Słowa kluczowe: rentowność, las, rachunkowość zarządcza.

Summary: Manufacture of wood is one of the longest natural production, lasting an average for about 100 years. Its specific conditions have a direct impact on the factors affecting revenues and costs associated with forest management. These factors determine the profitability of wood production and are related to the development phase of wood stands. Specific economic conditions of forest production are the direct cause of lack of possibility of direct implementation of management accounting tools taken from practises of manufacturing companies (including agricultural production) on the basis of units engaged in forestry. The 
aim of the article is: (1) to identify the factors affecting the profitability of wood production; (2) to group the determinants of wood production within the development phases of wood stands; (3) to determine the impact of the determinants of wood production for the opportunity to apply the tools of management accounting in companies which produce wood.

Keywords: profitability, forest, management accounting.

\section{Wstęp}

Zarządzanie polega na wyznaczaniu celów działania podmiotu gospodarczego i powodowaniu ich realizacji w sposób racjonalny. W przypadku gospodarstwa leśnego cele te sprowadzają się do spełnienia określonych jego funkcji, nazywanych również funkcjami lasu [Klocek 2001]. Jedną z takich funkcji jest produkcja drewna. Produkcja ta charakteryzuje się bardzo długim cyklem produkcyjnym, który w zależności od gatunku drzewa trwa zazwyczaj od 40 do 140 lat. Jest to produkcja przyrodnicza, która prowadzona jest powszechnie na terenie każdej gminy w Polsce. Już te dwie wskazane kwestie - długi cykl produkcji drewna i charakter produkcji przyrodniczej - determinują liczne, specyficzne dla gospodarki leśnej czynniki wpływające na rentowność głównego produktu użytkowania lasu. Mówiąc o produkcji drewna i jej związkach z czynnikami środowiska, powinniśmy uściślić, co jest drewnem i o jaką produkcję chodzi. Możliwe jest tu bowiem myślenie zarówno o przyroście (bieżącym czy przeciętnym), o rosnącym zapasie, o zasobności, o miąższości drzew i drzewostanów i o miąższości sortymentów sprzedawanych jako produkcja rynkowa leśnictwa. Ale możliwe jest również myślenie o procesach fizjologiczno-biochemicznych na poziomie fotosyntezy, bo tu właśnie odbywa się produkcja drewna/ksylemu i tu rozgrywa się najważniejszy jej etap [Rykowski 2012, s. 47-63]. $\mathrm{Z}$ uwagi na specyficzne uwarunkowania produkcji prowadzonej w lasach nie można jej odnieść do typowych przedsiębiorstw wytwórczych, czy nawet gospodarstw rolnych. W związku z tym nie można mówić o prostym (bezpośrednim) procesie zaadaptowania narzędzi rachunkowości zarządczej lub controllingu do działalności Państwowego Gospodarstwa Leśnego Lasy Państwowe (PGL LP) lub innej jednostki prowadzącej produkcję leśną.

Ponieważ większość narzędzi rachunkowości zarządczej bazuje na wykorzystaniu podstawowych kategorii ekonomicznych, do których zalicza się przychody i koszty, to autorzy opracowania zdecydowali się na przedstawienie złożoności zastosowania rachunkowości zarządczej w jednostkach prowadzących produkcję drewna przez pryzmat czynników wpływających na rentowność tejże produkcji. Celem artykułu jest: (1) zidentyfikowanie czynników wpływających na rentowność produkcji drewna; (2) pogrupowanie determinant produkcji drewna w ramach faz rozwojowych drzewostanów; (3) określenie wpływu determinant produkcji drewna na możliwość zastosowania narzędzi rachunkowości zarządczej w jednostkach produkujących drewno. Artykuł ma charakter teoretyczny i został napisany na podstawie badań literaturowych, 
wywiadów bezpośrednich z pracownikami nadleśnictw przy zastosowaniu metody dedukcji i indukcji.

\section{Ekonomiczne uwarunkowania produkcji drewna na tle faz rozwojowych drzewostanu}

Produkcja drewna prowadzona jest w lesie, który zgodnie z przepisami prawa stanowi grunt przeznaczony między innymi do produkcji leśnej [Ustawa z 28 września 1991]. Lasy publiczne stanowią około 81\%, zasobów leśnych w Polsce, z czego w zarządzie PGL LP ok. 71\%. Pozostałe 19\% lasów stanowi własność prywatną. Z punktu widzenia produkcji i sprzedaży drewna monopolistą jest PGL LP, które dostarcza ok. 95\% drewna na rynek krajowy.

Jak słusznie zauważa H. Szramka, „Specyficznymi zasobami produkcyjnymi w gospodarstwie leśnym są drzewostany, które w procesie produkcyjnym pełnią funkcję zarówno przedmiotu pracy, jak i środka pracy, a po wycięciu stają się efektem pracy" [Ważyński (red.) 2014, s. 374-375]. Taki stan rzeczy utrudnia prawidłowy rachunek efektywności produkcji leśnej. Dalej H. Szramka prezentuje najważniejsze z ekonomicznego punktu widzenia cechy produkcji leśnej, a mianowicie [Ważyński (red.) 2014, s. 378-379]:

- duże uzależnienie od warunków przyrodniczych;

- dhugi okres dojrzewania (wzrastania) drzewostanów;

- istnienie dwóch zakresów i dwóch okresów produkcji drzew: (1) zakres produkcji na pniu - okres wieloletni, (2) zakres produkcji przy pniu - okres jednoroczny;

- niewielki wpływ człowieka na wzrost wyników produkcji;

- trudności w prawidłowym ustalaniu produkcji globalnej leśnictwa;

- duża przestrzenność leśnych jednostek organizacyjno-administracyjnych w ramach PGL LP;

- sezonowość podporządkowana warunkom przyrodniczym;

- problemy z prawidłowym określeniem efektów gospodarowania (drzewa jako środek i przedmiot pracy, a po ścięciu jako efekt w postaci drewna).

Wszystkie powyższe ekonomiczne cechy warunkujące produkcję drewna można sprowadzić do dwóch zasadniczych, a mianowicie:

1. Produkcja ma charakter przyrodniczy.

2. Okres produkcji jest bardzo długi.

Produkcja drewna $\mathrm{z}$ uwagi na długi okres produkcyjny dzielona jest na kilka faz rozwojowych drzewostanów z uwzględnieniem uwarunkowań przyrodniczych związanych $z$ wiekiem dla danego gatunku drzew. Abstrahując jednak od typu gatunkowego drzew, proces produkcji leśnej można podzielić na następujące fazy rozwojowe:

- uprawa,

- młodnik, 
- tyczkowina,

- drągowina,

- drzewostan dojrzewający,

- drzewostan dojrzały (rębny),

- drzewostan przeszłorębny.

Wiek rębności (okres od uprawy do drzewostanu dojrzałego) jest różny, uzależniony od gatunku drzew. Przykładowo, wynosi on: 40 lat (topola), 60 lat (osika), 80 lat (brzoza, grab, świerk), 100 lat (sosna, buk, modrzew), 140 lat (dąb, jesion). Drzewostan przeszłorębny nie jest pożądany z punktu widzenia gospodarczego produkcji drewna, ponieważ obniża się jego jakość. Jednak w ramach realizacji funkcji ekologicznych lasu, zrównoważonej gospodarki leśnej drzewostan taki ma istotne znaczenie.

Każdej z faz można przypisać typowe zabiegi pielęgnacyjne, które są źródłem kosztów i mogą być jednocześnie źródłem przychodów (tab. 1).

Tabela 1. Ponoszenie kosztów i osiąganie przychodów w fazach rozwojowych drzewostanów

\begin{tabular}{|l|c|c|c|}
\hline \multicolumn{1}{|c|}{ Faza } & Zabieg pielęgnacyjny/ rębnia & Koszty & Przychody \\
\hline uprawa & czyszczenia wczesne & $\mathrm{X}$ & brak $^{*}$ \\
\hline młodnik & czyszczenia późne & $\mathrm{X}$ & brak \\
\hline tyczkowina & trzebieże wczesne & $\mathrm{X}$ & $\mathrm{X}$ \\
\hline drągowina & trzebieże późne & $\mathrm{X}$ & $\mathrm{X}$ \\
\hline drzewostan dojrzewający & $\begin{array}{c}\text { trzebieże późne/ cięcia } \\
\text { pielęgnacyjne }\end{array}$ & $\mathrm{X}$ & $\mathrm{X} ?$ \\
\hline drzewostan dojrzały & rębnia & $\mathrm{X}$ & $\mathrm{X}$ \\
\hline $\begin{array}{l}\text { drzewostan przeszłorębny } \\
\text { rębnia lub jej brak/ cięcia } \\
\text { pielęgnacyjne }\end{array}$ & $\mathrm{X}$ & $\mathrm{X} ?$ \\
\hline
\end{tabular}

${ }^{*} \mathrm{Z}$ uwagi na fakt, że w pierwszych fazach rozwojowych nie ma jeszcze drewna (grubizny), to w fazach upraw i młodników nie ma przychodów. Są tylko koszty związane z koniecznością przywracania stanu właściwego po ich poniesieniu, nie ma już to wpływu na przychody.

Oznaczenia: X - występuje dana kategoria ekonomiczna, X? - występuje dana kategoria ekonomiczna w określonych sytuacjach.

Źródło: opracowanie własne.

Zgodnie z treścią tab. 1 można stwierdzić, że rentowność produkcji drewna jest zdeterminowana zarówno od strony przychodowej, jak i kosztowej prawie w każdej fazie rozwoju drzewostanów. W związku z tym celowe jest zidentyfikowanie kluczowych czynników rentowności produkcji drewna w ujęciu kolejnych faz rozwojowych drzewostanów i dopiero na tym tle odniesienie się do możliwości zaadaptowania rozwiązań z zakresu rachunkowości zarządczej, wypracowanych w jednostkach 
nieprowadzących gospodarki leśnej, na grunt PGL LP lub innych jednostek zajmujących się produkcją leśną.

\section{Czynniki determinujące rentowność produkcji drewna w ujęciu kolejności faz rozwojowych drzewostanów}

Jak wstępnie stwierdzono, rentowność produkcji drewna na poszczególnych etapach rozwoju drzewostanów może być uzależniona od czynników wpływających zarówno na przychody, jak i koszty tejże produkcji. Należy jednak przeprowadzić w tym miejscu pogłębioną analizę, ukierunkowaną na identyfikację czynników determinujących stronę przychodową i kosztową rentowności produkcji drewna.

W każdej fazie rozwojowej drzewostanów można zidentyfikować ogólne grupy czynników wpływających na rentowność produkcji drewna. Autorzy pogrupowali je w pierwszej kolejności w sposób bardzo ogólny do trzech zespołów, a mianowicie:

1. Czynniki abiotyczne.

2. Czynniki biotyczne.

3. Czynniki antropogeniczne.

Główne źródła zagrożeń czynników abiotycznych, biotycznych i antropogenicznych w ramach ochrony lasu i ich wpływ na stronę przychodową i kosztową rentowności produkcji drewna $\mathrm{w}$ ramach poszczególnych faz rozwoju drzewostanów przedstawiono w tab. 2. Nadane rangi z zakresu od 0 (brak wpływu) do 5 (kluczowy wpływ) wskazują na istotność danego czynnika w kształtowaniu kosztów i przychodów produkcji drewna. Przyjęty podział na siedem faz rozwoju drzewostanów należy uznać za celowy w tym przypadku, ponieważ odzwierciedla długi proces produkcji i specyficzne determinanty rentowności produkcji leśnej. Zaistnienie określonych czynników na wczesnym etapie produkcji (uprawa, młodnik) może mieć duże znaczenie nie tylko dla kosztów ponoszonych w tych fazach produkcji, ale także dla przychodów, których kulminacja ma miejsce w fazie drzewostanu dojrzałego. W związku z tym w przypadku rang odnoszących się do przychodów (P) należy mieć na uwadze, że przychód ten będzie osiągnięty niekoniecznie w tej fazie, w której dany czynnik zaistniał. Natomiast ranga nadana po stronie kosztowej (K) najczęściej będzie determinować koszty tej samej fazy rozwoju drzewostanów lub kolejnej. Autorzy w tym miejscu z uwagi na ograniczenia rozmiaru publikacji nie dokonują analizy kierunku oddziaływania poszczególnych czynników na wzrost/ zmniejszenie kosztów i przychodów. Zagadnienia te są przedmiotem kolejnego etapu prowadzonych badań.

Analiza treści tab. 2 skłania do następujących wniosków:

- $\quad$ z czynników abiotycznych to wiatr i opady atmosferyczne w największym stopniu mogą wpłynąć na rentowność produkcji drewna; z czynników biotycznych choroby drzew wywołane patogenami; z czynników antropogenicznych - pożary i szkodnictwo leśne;

- drzewostany w fazie uprawy i młodnika są tym etapem produkcji drewna, kiedy większość czynników stosunkowo silnie oddziałuje na koszty produkcji; 
Tabela 2. Główne determinanty rentowności produkcji drewna po stronie kosztowej i przychodowej

\begin{tabular}{|c|c|c|c|c|c|c|c|c|c|c|c|c|c|c|c|}
\hline \multirow{3}{*}{ Grupa czynników } & \multirow{3}{*}{ Wyszczególnienie } & \multicolumn{14}{|c|}{ Faza rozwoju drzewostanów } \\
\hline & & \multicolumn{2}{|c|}{ uprawa } & \multicolumn{2}{|c|}{ młodnik } & \multicolumn{2}{|c|}{ tyczkowina } & \multicolumn{2}{|c|}{ drągowina } & \multicolumn{2}{|c|}{$\begin{array}{c}\text { drzewostan } \\
\text { dojrzewający }\end{array}$} & \multicolumn{2}{|c|}{$\begin{array}{c}\text { drzewostan } \\
\text { dojrzały }\end{array}$} & \multicolumn{2}{|c|}{$\begin{array}{c}\text { drzewostan } \\
\text { przeszłorębny }\end{array}$} \\
\hline & & K & $P$ & $\mathrm{~K}$ & $\mathrm{P}$ & K & $P$ & K & $\mathrm{P}$ & K & $P$ & $\mathrm{~K}$ & $\mathrm{P}$ & $\mathrm{K}$ & $P$ \\
\hline \multirow{8}{*}{ 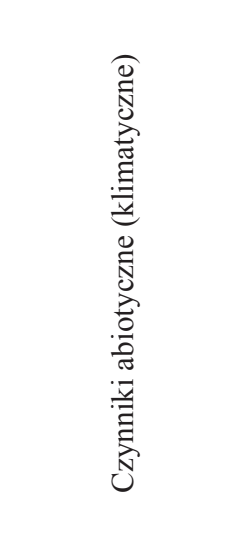 } & światło & 1 & 0 & 1 & 0 & 1 & 1 & 2 & 0 & 2 & 2 & 0 & 0 & 0 & 0 \\
\hline & temperatura & 5 & 0 & 4 & 0 & 2 & 1 & 1 & 1 & 1 & 1 & 1 & 2 & 1 & 2 \\
\hline & wiatry & 4 & 0 & 3 & 0 & 2 & 4 & 4 & 4 & 4 & 5 & 4 & 5 & 4 & 4 \\
\hline & $\begin{array}{l}\text { wyładowania } \\
\text { atmosferyczne }\end{array}$ & 0 & 0 & 0 & 0 & 0 & 0 & 0 & 0 & 0 & 0 & 1 & 1 & 1 & 1 \\
\hline & opady atmosferyczne & 2 & 0 & 2 & 0 & 4 & 3 & 4 & 4 & 3 & 3 & 2 & 3 & 1 & 1 \\
\hline & $\begin{array}{l}\text { nadmiar i niedobór } \\
\text { wody w glebie }\end{array}$ & 3 & 0 & 2 & 0 & 1 & 1 & 1 & 1 & 1 & 1 & 1 & 1 & 1 & 1 \\
\hline & $\begin{array}{l}\text { nadmiar i niedobór } \\
\text { substancji } \\
\text { pokarmowych }\end{array}$ & 3 & 0 & 1 & 0 & 1 & 1 & 1 & 1 & 1 & 1 & 1 & 1 & 1 & 1 \\
\hline & erozja & 2 & 0 & 2 & 0 & 2 & 2 & 2 & 1 & 2 & 2 & 2 & 2 & 2 & 2 \\
\hline \multirow{3}{*}{ 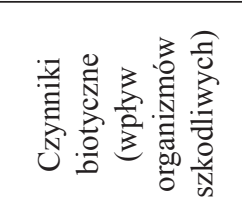 } & $\begin{array}{l}\text { choroby drzew } \\
\text { wywołane patogenami }\end{array}$ & 4 & 0 & 3 & 0 & 2 & 0 & 1 & 1 & 0 & 2 & 0 & 2 & 0 & 3 \\
\hline & szkodliwe owady leśne & 4 & 0 & 3 & 0 & 0 & 0 & 0 & 0 & 0 & 1 & 0 & 1 & 0 & 2 \\
\hline & $\begin{array}{l}\text { szkody wywołane } \\
\text { przez ssaki }\end{array}$ & 5 & 0 & 4 & 0 & 3 & 0 & 0 & 0 & 0 & 0 & 0 & 0 & 0 & 0 \\
\hline
\end{tabular}




\begin{tabular}{|c|c|c|c|c|c|c|c|c|c|c|c|c|c|c|c|}
\hline \multirow{9}{*}{ 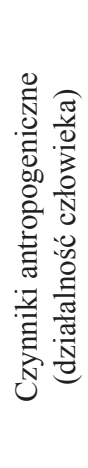 } & urbanizacja & 1 & 0 & 1 & 0 & 1 & 2 & 1 & 2 & 1 & 2 & 1 & 2 & 1 & 1 \\
\hline & przemysł wydobywczy & 0 & 0 & 0 & 0 & 1 & 0 & 0 & 0 & 0 & 0 & 0 & 0 & 0 & 0 \\
\hline & przemysł energetyczny & 0 & 0 & 0 & 0 & 0 & 0 & 0 & 0 & 0 & 0 & 0 & 0 & 0 & 0 \\
\hline & przemysł przetwórczy & 0 & 0 & 0 & 0 & 0 & 0 & 0 & 0 & 0 & 0 & 0 & 0 & 0 & 0 \\
\hline & komunikacja & 1 & 0 & 0 & 0 & 0 & 0 & 0 & 0 & 0 & 0 & 0 & 0 & 0 & 0 \\
\hline & gospodarstwa rolne & 0 & 0 & 0 & 0 & 0 & 0 & 0 & 0 & 0 & 0 & 0 & 0 & 0 & 0 \\
\hline & $\begin{array}{l}\text { zanieczyszczenie } \\
\text { środowiska }\end{array}$ & 3 & 0 & 3 & 0 & 3 & 0 & 3 & 1 & 0 & 2 & 0 & 2 & 0 & 3 \\
\hline & pożary & 5 & 0 & 5 & 0 & 5 & 1 & 5 & 3 & 5 & 4 & 4 & 5 & 4 & 5 \\
\hline & szkodnictwo leśne & 3 & 0 & 3 & 0 & 3 & 0 & 2 & 1 & 1 & 2 & 1 & 3 & 1 & 3 \\
\hline
\end{tabular}

Oznaczenia: 0 - brak wpływu; 1 - niewielki wpływ; 2 - umiarkowany wpływ; 3 - duży wpływ; 4 - bardzo duży wpływ; 5 - kluczowy wpływ. $\mathrm{P}$ - przychody; K - koszty.

Źródło: opracowanie własne. 
- trzy końcowe fazy rozwoju drzewostanów charakteryzują się znaczącym wpływem większości czynników na przychody z produkcji drewna.

Pozostałe czynniki determinujące rentowność produkcji drewna można zebrać do następujących grup:

1. Typ siedliska (nizinne, wyżynne, górskie, wysokogórskie).

2. Żyzność siedliska warunkująca urodzajność i skład gatunkowy (bory, bory mieszane, lasy mieszane, las).

3. Czynniki ludzkie (kompetencje nadleśniczych i ich podwładnych oraz pracowników dyrekcji regionalnych i dyrekcji generalnej).

4. Rodzaje rębni (zupełna, częściowa, gniazdowa, stopniowa, przerębowa).

5. System sprzedaży drewna (system drewna krótkiego, system drewna długiego, system całego drewna, system drewna sypkiego).

Wszystkie podane czynniki odznaczają się wpływem zarówno na stronę kosztową produkcji drewna (szczególnie typ siedliska, rodzaj rębni), jak i przychodową (przede wszystkim system sprzedaży drewna i czynnik ludzki).

\section{Możliwości implementacji rozwiązań z zakresu rachunkowości zarządczej w jednostkach produkujących drewno}

Rachunkowość najczęściej rozpatrywana jest jako system informacyjny jednostek gospodarczych. Informacje generowane przez system rachunkowości muszą być wiarygodne, rzetelne, kompletne i dostarczane na czas [Sadowska 2015]. Należy jednak zgodzić się z M. Gmytrasiewicz, A. Karmańską i J. Turyną, że zacierają się granice między rachunkowością a innymi systemami informacyjnymi jednostek [Gmytrasiewicz, Karmańska 2006, s. 27; Turyna 1997, s. 92]. W przypadku PGL LP system informatyczny SILP to nie tylko klasyczny system finansowo-księgowy. System ten wspomaga zarządzanie przy wykorzystaniu rachunkowości oraz innych systemów informacyjnych, tworząc kompleksowy zbiór danych i informacji możliwych do wykorzystania na różnym stopniu zarządzania (dyrekcja generalna, dyrekcje regionalne, nadleśnictwa, leśnictwa).

System rachunkowości PGL LP bazuje przede wszystkim na rozwiązaniach typowych dla podsystemu rachunkowości finansowej (księgi rachunkowe z kontami syntetycznymi i analitycznymi, inwentaryzacja, rachunek kosztów pełnych, sprawozdawczość finansowa). Jednak w przekonaniu autorów w najbliższych latach należy się spodziewać systemowego wdrażania rozwiązań z zakresu rachunkowości zarządczej, które obok danych ilościowych i wartościowych uwzględniają także te jakościowe. Produkcja drewna jest podstawowym zadaniem prowadzonym $\mathrm{w}$ ramach gospodarki leśnej, ale nie jedynym. W zależności od grupy interesariuszy można wskazać na inne cele gospodarki leśnej prowadzonej przez PGL LP. Cele te związane są tak zwanymi pozaprodukcyjnymi funkcjami lasu, a mianowicie funkcjami ekologicznymi i społecznymi, które dla większości ludzi stawiane są na pierwszym 
miejscu. Stąd dochodzi do niezrozumienia przez społeczeństwo zasad prowadzonej gospodarki leśnej. Rachunkowość zarządcza w ramach swojego instrumentarium może uwzględnić nie tylko czynniki ekonomiczne, ale także te ekologiczne i społeczne. Jednak w pierwszej kolejności autorzy uważają, że należy dokonać wstępnej oceny możliwości implementacji rozwiązań z zakresu rachunkowości zarządczej wypracowanych w jednostkach spoza sektora leśnego na jego grunt przy uwzględnieniu podstawowych kategorii ekonomicznych, stanowiących podstawę w procesach decyzyjnych, a mianowicie kosztów i przychodów.

Rozważania poczynione wcześniej, dotyczące determinant rentowności produkcji drewna po stronie kosztowej i przychodowej w ujęciu faz rozwoju drzewostanów, oraz pozostałe pięć grup czynników skłaniają do następujących wniosków:

1. Instrumenty rachunkowości zarządczej w formule stosowanej w jednostkach produkcyjnych, w tym produkcji rolnej jako tej najbardziej zbliżonej do produkcji drewna, nie powinny być w sposób bezpośredni adaptowane na grunt jednostek zajmujących się produkcją drewna.

2. Narzędzia rachunkowości zarządczej w jednostkach prowadzących produkcję drewna powinny zostać opracowane od podstaw, jako nowe rozwiązania niemające swoich odpowiedników w polskiej praktyce jednostek nieprowadzących gospodarki leśnej, lub w sposób ewolucyjny poddane procesowi implementacji (znaczącej implementacji) przy wykorzystaniu doświadczeń rozwiązań z polskiej praktyki gospodarczej oraz jednostek produkujących drewno z innych krajów.

Wnioski te zostały podane na podstawie następujących przesłanek, świadczących o specyficznych uwarunkowaniach produkcji drewna:

Tabela 3. Grupy problemowe rachunkowości ukierunkowanej na implementację rozwiązań z zakresu rachunkowości zarządczej do jednostek produkujących drewno

\begin{tabular}{|c|c|c|}
\hline Problemy & Przedmiot odniesienia - ogólnie & $\begin{array}{c}\text { Przedmiot odniesienia - rachunkowość } \\
\text { zarządcza w jednostkach produkujących } \\
\text { drewno (ze szczególnym uwzględnieniem } \\
\text { PGL LP) }\end{array}$ \\
\hline 1 & 2 & 3 \\
\hline Merytoryczne & $\begin{array}{l}\text { - Przedmiot pomiaru (identyfikacja, } \\
\text { definicja, klasyfikacja). } \\
\text { - Związki między różnymi } \\
\text { wielkościami charakteryzującymi } \\
\text { zjawiska gospodarcze. } \\
\text { - Reguły metodologiczne poznania } \\
\text { i modelowe ujęcia złożonej } \\
\text { rzeczywistości gospodarczej } \\
\text { podmiotu (teoretyczna podstawa } \\
\text { budowy systemów rachunkowości). }\end{array}$ & $\begin{array}{l}\text { - Zasoby w postaci drzewostanów, } \\
\text { które są jednocześnie przedmiotem, } \\
\text { środkiem pracy i efektem finalnym; } \\
\text { liczne produkty uboczne, w tym } \\
\text { większość świadczona za darmo, przy } \\
\text { jednoczesnym ponoszeniu kosztów. } \\
\text { - Zużycie zasobów środowiska a efekty } \\
\text { rzeczowe. } \\
\text { - Włączenie do modelu rachunkowości } \\
\text { zarządczej złożonej rzeczywistości } \\
\text { PGL LP (ekonomia - środowisko } \\
\text { naturalne - społeczeństwo). }\end{array}$ \\
\hline
\end{tabular}


Tabela 3, cd.

\begin{tabular}{|c|c|c|}
\hline 1 & 2 & 3 \\
\hline Metodologiczne & $\begin{array}{l}\text { Sposoby pomiaru; wybór metody } \\
\text { zależy od przyjętej definicji } \\
\text { przedmiotu i oczekiwanego stopnia } \\
\text { dokładności pomiaru, możliwości } \\
\text { i opłacalności zastosowania danej } \\
\text { metody oraz przyjętej polityki } \\
\text { rachunkowości uwarunkowanej } \\
\text { celem pomiaru. }\end{array}$ & $\begin{array}{l}\text { Definicje przedmiotu pomiaru } \\
\text { przychodów, kosztów, efektów, korzyści } \\
\text { ekonomicznych, ekologicznych } \\
\text { i społecznych produkcji drewna we } \\
\text { wszystkich fazach rozwojowych } \\
\text { drzewostanów. }\end{array}$ \\
\hline Proceduralne & $\begin{array}{l}\text { Możliwe do zastosowania procedury } \\
\text { grupowania, rozliczania i kalkulacji } \\
\text { wielkości ekonomicznych w procesie } \\
\text { tworzenia informacji retro- } \\
\text { i prospektywnych. }\end{array}$ & $\begin{array}{l}\text { Problemy grupowania, rozliczania } \\
\text { i kalkulacji wielkości ekonomicznych } \\
\text { produkcji drewna w długim czasie } \\
\text { produkcji (np. } 100 \text { lat). Ponadto } \\
\text { problematyka ujęcia i uwidocznienia } \\
\text { środowiskowych i społecznych kosztów } \\
\text { i korzyści działalności PGL LP. }\end{array}$ \\
\hline Formalne & $\begin{array}{l}\text { Formy ujmowania odpowiednich } \\
\text { wielkości w urządzeniach } \\
\text { ewidencyjnych i planistycznych } \\
\text { oraz prezentacji w sprawozdaniach } \\
\text { (raportach) przeznaczonych dla } \\
\text { różnych użytkowników. }\end{array}$ & $\begin{array}{l}\text { Przełożenie przedsięwzięć } \\
\text { produkcyjnych, ekologicznych, } \\
\text { społecznych z planu urządzenia lasu } \\
\text { do systemu rachunkowości zarządczej } \\
\text { (perspektywa } 10 \text { lat, co z kolejnymi } \\
\text { okresami produkcji drewna?). Zakres } \\
\text { i rodzaj prezentowanej informacji na } \\
\text { poziomie dyrekcji, nadleśnictw PGL } \\
\text { LP oraz odbiorców zewnętrznych } \\
\text { (organizacje ekologiczne, społeczeństwo, } \\
\text { zakłady usług leśnych). }\end{array}$ \\
\hline Techniczne & $\begin{array}{l}\text { Potrzeba, możliwości, zakres } \\
\text { i sposoby zastosowania techniki } \\
\text { komputerowej przetwarzania danych. }\end{array}$ & $\begin{array}{l}\text { Dostosowanie systemu informatycznego } \\
\text { SILP do potrzeb związanych } \\
\text { z rachunkowością zarządczą. }\end{array}$ \\
\hline Organizacyjne & $\begin{array}{l}\text { Organizacja funkcjonowania systemu } \\
\text { rachunkowości w powiązaniu } \\
\text { z innymi systemami informacyjnymi } \\
\text { zarządzania. }\end{array}$ & $\begin{array}{l}\text { Umiejscowienie instrumentarium } \\
\text { rachunkowości zarządczej w układzie } \\
\text { informacyjnym podporządkowanym } \\
\text { wymaganiom i ograniczeniom SILP. }\end{array}$ \\
\hline
\end{tabular}

Źródło: opracowanie własne na podstawie [Stępień 2003].

- koszty produkcji drewna ponoszone są w każdej fazie rozwoju drzewostanów i mają na nie wpływ różnorodne czynniki, które są trudne do przewidzenia (w licznych przypadkach należą do grupy niemierzalnej - niepewności, a część do ryzyka, które jednak trudno jest zmierzyć); ponadto koszty te dotyczą bardzo długiego okresu, w związku z czym bardzo często nie ma możliwości ustalenia wiarygodnej ich wartości z okresu sprzed 50-80 lat;

- przychody z danej produkcji drewna nie są osiągane w tym samym czasie z uwagi na odchodzenie od rębni zupełnych, jak i zabiegów pielęgnacyjnych w fazach 
przed drzewostanem dojrzałym; ponadto wpływ na ich wartość mogą mieć czynniki trudne do przewidzenia.

Wyartykułowane przesłanki nie zamykają listy argumentów potwierdzających słuszność wniosków o braku możliwości bezpośredniej implementacji rozwiązań rachunkowości zarządczej na grunt jednostek produkujących drewno. Dodatkowo można wskazać na problemy natury: merytorycznej, metodologicznej, proceduralnej, formalnej, technicznej oraz organizacyjnej. Charakterystykę wskazanych grup problemowych przedstawiono $\mathrm{w}$ tab. 3 .

Przytoczona argumentacja potwierdza prawdziwość sformułowanych wcześniej wniosków o braku bezpośredniej implementacji wypracowanych w jednostkach niezwiązanych z gospodarką leśną rozwiązań z zakresu rachunkowości zarządczej do jednostek prowadzących produkcję drewna.

\section{Zakończenie}

Podsumowując, należy stwierdzić, że zostały zrealizowane postawione cele. Jednak z uwagi na ograniczone rozmiary opracowania nie wyczerpują one samego tematu, jak i argumentacji. Autorzy prowadzą pogłębione badania, a ich wyniki będą stanowić kolejne publikacje.

Zidentyfikowane determinanty rentowności produkcji drewna w ujęciu faz rozwojowych drzewostanów zostały pogrupowane do trzech zasadniczych grup (czynniki biotyczne, abiotyczne i antropogeniczne) oraz do pięciu dodatkowych (typ siedliska, żyzność siedliska, czynnik ludzki, rodzaj rębni, system sprzedaży drewna). Różnorodność tych czynników, możliwość jednoczesnego ich występowania, a przede wszystkim niepewność lub trudne do określenia ryzyko ich występowania na różnych etapach bardzo długiego cyklu produkcji drewna są podstawową przyczyną braku możliwości łatwej implementacji instrumentów rachunkowości zarządczej w jednostkach prowadzących gospodarkę leśną.

\section{Literatura}

Gmytrasiewicz M., Karmańska, A., 2006, Rachunkowość finansowa, Difin, Warszawa.

Klocek A., 2001, Problemy zarządzania wielofunkcyjnym gospodarstwem leśnym, Prace Instytutu Badawczego Leśnictwa, ser. A, 924, Sękocin Stary, s. 24-43.

Rykowski K., 2012, Czynniki środowiska przyrodniczego determinujace produkcję drewna, [w:] Przyrodnicze i gospodarcze aspekty produkcji oraz wykorzystania drewna - stan obecny i prognoza, Wydawnictwo IBL, Sękocin Stary s. 47-63.

Sadowska B., 2015, Rachunkowość w Państwowym Gospodarstwie Leśnym Lasy Państwowe, Prace Naukowe Uniwersytetu Ekonomicznego we Wrocławiu, nr 390, UE, Wrocław, s. 222-233.

Stępień M., 2003, Rachunkowość ekologiczna w świetle idei spotecznej odpowiedzialności przedsiębiorstw, Zeszyty Naukowe nr 633. Prace z zakresu rachunkowości finansowej, Wydawnictwo Akademii Ekonomicznej w Krakowie, Kraków, s. 45. 
Turyna J., 1997, System informacyjny rachunkowości w podejmowaniu decyzji zarzadczych, Wydawnictwo Naukowe Wydziału Zarządzania Uniwersytetu Warszawskiego, Warszawa.

Ustawa z 28 września 1991 r. o lasach, Dz.U. nr 101, poz. 444 ze zm.

Ważyński B. (red.), 2014, Podstawy gospodarki leśnej, Wydawnictwo Uniwersytetu Przyrodniczego w Poznaniu, Poznań. 